\title{
Seasonal fluctuations in pituitary levels of the three forms of gonadotropin-releasing hormone in striped bass, Morone saxatilis (Teleostei), during juvenile and pubertal development
}

\author{
M C Holland, S Hassin and Y Zohar \\ Center of Marine Biotechnology, University of Maryland Biotechnology Institute, 701 East Pratt Street, Baltimore, Maryland 21202, USA \\ (Requests for offprints should be addressed to Y Zohar; Email: zohar@umbi.umd.edu) \\ (M C Holland is now at Institute of Molecular Biology and Biotechnology, PO Box 1527, Vassilika Vouton, Heraklion, Crete 71110, Greece)
}

\begin{abstract}
In most vertebrates, the development of a mature gonadotropin-releasing hormone $(\mathrm{GnRH})$ secretory system is pivotal for the onset of puberty. The role of the three native GnRH forms, seabream (sb) GnRH, chicken (c) GnRH-II and salmon GnRH, in striped bass puberty remains elusive. This study examined the changes in pituitary GnRH levels throughout juvenile and pubertal development, a period encompassing 3 to 4 years. The levels of the two most abundant forms in the pituitary, sbGnRH and cGnRH-II (10:1), increased during the Fall and peaked prior to (cGnRH-II) or during (sbGnRH) the natural breeding season in March to May. In most cases, sbGnRH and cGnRH-II levels of maturing fish correlated
\end{abstract}

to changes in oocyte diameter, gonadosomatic index and LH pituitary content. Interestingly, pituitaries of immature and maturing 2- and 3-year-old males and females contained similar amounts of all three GnRH forms. Additionally, pituitary sbGnRH and cGnRH-II levels in juvenile fish were relatively high and $\mathrm{GnRH}$ profiles showed a clear seasonality, similar to those of older, mature fish. These findings suggest a role for both sbGnRH and cGnRH-II in the regulation of gonadal development and indicate that, unlike some mammalian species, the timing of puberty in striped bass is not limited by a low activity of the GnRH system.

Journal of Endocrinology (2001) 169, 527-538

\section{Introduction}

Pubertal development is the result of an activation of the brain-pituitary-gonad axis leading to increased levels of the various reproductive hormones and the initiation of gameteogenesis. In mammals, gonadotropin-releasing hormone $(\mathrm{GnRH})$ plays a critical role in this process since the timing of puberty is determined by the development of a mature pulsatile $\mathrm{GnRH}$ secretory system (Ojeda \& Urbanski 1994, Plant 1994). Also in lower vertebrates, an increased activity of the GnRH system is believed to be crucial for the initiation of gonadal development (Rastogi et al. 1990, Schreibman et al. 1991, Amano et al. 1992). In fish, a hypophyseal portal system is absent and GnRH neurons from distinct brain areas project to the pituitary where they innervate the gonadotrophs (Anglade et al. 1993). Due to this anatomical organization, actual GnRH release cannot be measured and researchers have used the abundance of $\mathrm{GnRH}$ in the pituitary as an indicator of GnRH-releasing activity. Even though pituitary GnRH content does not differentiate between GnRH stored in the axonal endings of $\mathrm{GnRH}$ neurons and GnRH released from these neurons, positive relationships have been observed between gonadal development and the amount of $\mathrm{GnRH}$ in the pituitary. For instance, in the masu salmon, Oncorhynchus masou, pituitary GnRH levels are low in juvenile animals, but the levels increase during puberty when the gonads start to increase in size and the processes of vitellogenesis and spermatogenesis are initiated (Amano et al. 1992, 1993). Elevated pituitary GnRH levels are likely to be the result of an increased GnRHsynthesizing activity; however, clear correlations between brain GnRH levels and gonadal maturation cannot always be detected (Yu et al. 1987, Okuzawa et al. 1990, Amano et al. 1993). This lack of correlation may be related to the involvement of $\mathrm{GnRH}$ in non-pituitary-related processes by acting as a neurotransmitter and/or neuromodulator elsewhere in the brain (Oka 1997). Because the functions of GnRH in the pituitary are, most probably, limited to the regulation of the synthesis and release of pituitary hormones, such as follicle-stimulating hormone (FSH) and luteinizing hormone (LH), correlations between gonadal development and GnRH levels are more likely to be obtained with pituitary than brain levels.

Studies on the involvement of $\mathrm{GnRH}$ in the various reproductive processes have been complicated by the discovery of multiple GnRH forms within the brain of a single species (Rastogi et al. 1990, Powell et al. 1994, 
Gothilf et al. 1995, Lescheid et al. 1997, Montaner et al. 1998). In mammals, the hypothalamic GnRH form, LH-releasing hormone or mammalian (m) GnRH, can be detected in hypophyseal portal blood and has been implicated in the regulation of gonadotropin secretion (Fink 1988). In some fishes, such as salmonids, only one of the two native GnRH forms reaches the pituitary and, thus, controls gonadotropin activity (Okuzawa et al. 1990, Amano et al. 1992). Pituitaries of other fishes, however, contain multiple GnRH forms, all of which have been shown to possess gonadotropin-releasing activity (Zohar et al. 1995). The identification of the reproductionrelevant form(s) in these animals rests predominantly on its abundance in the pituitary and correlation to reproductive development. For instance, in the European eel, Anguilla anguilla, both $\mathrm{mGnRH}$ and chicken (c) GnRH-II can be detected in the pituitary, but the levels of $\mathrm{mGnRH}$ are higher than those of cGnRH-II and only the profile of mGnRH correlates to gonadal development (Dufour et al. 1993). In the more evolved and largest order of fishes, the perciformes, three $\mathrm{GnRH}$ variants are produced in the brain, seabream (sb) GnRH, cGnRH-II and salmon (s) GnRH (Powell et al. 1994, Gothilf et al. 1996). Within this order, considerable species differences exist in the number of forms that reach the pituitary (Powell et al. 1995, White et al. 1995, Weber et al. 1997, Holland et al. 1998a, Senthilkumaran et al. 1999). However, in all cases examined, the dominant pituitary form is $\mathrm{sbGnRH}$, which is also the form that shows the highest correlation to gonadal development in the gilthead seabream, Sparus aurata (Holland et al. 1998a) and red seabream, Pagrus major (Senthilkumaran et al. 1999). Therefore, sbGnRH may be the primary regulator of gonadotropin activity, and thus gonadal development, in perciform fishes. Thorough studies examining the relationships between pituitary GnRH content and gonadotropin levels or gonadal development are still sparse. The reason for this lack of information may lay in the difficulty with which specific immunoassays for each of the three GnRH forms can be developed, as well as the large number of animals that need to be killed for this type of study.

The striped bass, Morone saxatilis, is a seasonal breeding teleost of the order perciformes. The distibution of the three GnRH forms in the brain of this species has been described previously (Gothilf et al. 1995). As in other perciformes, sbGnRH is the only form expressed in the preoptic area, an area known to contain neurons that project to the pituitary (Anglade et al. 1993, Okuzawa et al. 1997). Because GnRH appears to be a limiting factor for pubertal development in vertebrates, investigating the changes in pituitary $\mathrm{GnRH}$ levels prior to and during pubertal maturation may shed some light on the involvement of the different forms in reproduction. Striped bass females display a relatively late puberty, with the majority of captive females initiating gonadal development at 3 years of age. Although oocyte diameter increases during the third year, full maturity may not be reached until 1 to 2 years later, indicating that pubertal development in this species takes several years to be completed (Holland et al. 2000). Males, on the other hand, mature faster and about $60 \%$ of a captive male population reaches puberty during the first (Holland et al. 1996) and second year (Holland et al. 2000). The objective of the present work was to analyze the pituitary levels of the three native $\mathrm{GnRH}$ forms in striped bass during the first 4 years of life, using three sensitive and specific ELISAs recently developed in our laboratory (Holland et al. 1998a). Data on the changes in gonadal development, plasma steroid levels, and the levels of FSH (mRNA) and LH (mRNA and protein) during this period, using the same animals as the present study, have been reported previously (Hassin et al. 1999, 2000, Holland et al. 2000). The availability of these complementary data sets allows us to correlate the changes in pituitary GnRH levels that occur during juvenile and pubertal development to those of other major reproductive hormones and parameters. Together with our previously published work, the present study provides new insights into the onset and regulation of pubertal development in striped bass and, possibly, in late-maturing seasonally breeding perciformes in general.

\section{Materials and Methods}

\section{Fish and sampling}

Striped bass were produced from captive-reared broodstock of mixed Chesapeake Bay stock origin at the University of Maryland Crane Aquaculture Facility in April 1991 and 1993. When the fish reached the ages of 4 (1993 year class) and 26 months (1991 year class), they were transported to the Aquaculture Research Center of the Center of Marine Biotechnology, Baltimore, MD, USA. Fish were kept in $4 \mathrm{~m}^{3}$ recirculating systems at a maximum stocking density of $38 \mathrm{~kg} / \mathrm{m}^{3}$, under a simulated natural photo- and thermoperiod regime (gradual change from $13 \pm 1{ }^{\circ} \mathrm{C}$ and $8 \mathrm{~h}$ light: $16 \mathrm{~h}$ darkness (8L:16D) in the winter to $23 \pm 1{ }^{\circ} \mathrm{C}$ and $16 \mathrm{~L}: 8 \mathrm{D}$ in the summer) and at 10 ppt salinity (Forty Fathoms marine mix; Marine Enterprises Inc., Baltimore, MD, USA). They were fed daily with a commercial diet (Zeigler Inc., Gardners, PA, USA) at a rate varying from 3.0 to $0.9 \%$ of their body weight depending on age and size. During the course of the experiment, fish from both year classes were graded several times according to body weight and only the fish of the medium-size group (the majority of the animals) were sampled. All animals at the Aquaculture Research Center were maintained and sampled according to protocols approved by the Institutional Animal Care and Use Committee of the University of Maryland Biotechnology Institute.

Monthly samplings of both populations started in February 1994 and continued until April 1995 for the 
1991 year class and until January 1996 for the 1993 year class. Since all males had reached maturity during the third year of life, only females were sampled during the fourth year. At each sampling time, 15-20 fish were randomly collected and anesthetized in a $0.25 \mathrm{ml} / 1$ solution of 2-phenoxyethanol (J T Baker Inc., Phillipsburg, NJ, USA). After decapitation, pituitaries were removed and immediately frozen in liquid nitrogen. Plasma was collected after centrifugation of the blood for the determination of gonadal steroids (Holland et al. 2000) and LH (Hassin et al. 1999) levels. Pituitaries and plasma were stored at $-80{ }^{\circ} \mathrm{C}$ until further analyses. The gonads were removed, weighed for calculation of the gonadosomatic index (GSI; (gonad weight/body weight) $\times 100$ ), and fragments taken from the mid-section of the gonad were fixed for histology. Oocyte diameter and morphology were examined under a $100 \times$ magnification and the diameter of ten of the largest oocytes were recorded from each fish. Only oocytes that were cut through the nucleus were measured. The fish were categorized as juvenile or maturing/mature according to previously established criteria (Holland et al. 2000).

\section{Pituitary extraction}

Pituitaries were homogenized in $200 \mu \mathrm{LiCl} /$ urea solution ( $3 \mathrm{M}$ lithium chloride and $6 \mathrm{M}$ urea). Of the homogenate, $90 \mu \mathrm{l}$ was diluted in $810 \mu \mathrm{l}$ ELISA buffer for GnRH determination while $10 \mu \mathrm{l}$ of the homogenate was aspirated and diluted in $1 \mathrm{ml}$ PBST (100 mM phosphatebuffered serum containing $0 \cdot 05 \%$ Tween 20 ) for gonadotropin II and total protein content (Micro BCA kit; Pierce, Rockford, IL, USA) measurements (Hassin et al. 1999, 2000). Pituitary extracts were frozen at $-80{ }^{\circ} \mathrm{C}$ until further analysis. The remaining $100 \mu \mathrm{l}$ of the homogenate was used to measure the mRNA levels of the $\alpha-$, FSH $\beta$ and LH $\beta$ subunits by ribonuclease protection assay, and the results are reported by Hassin et al. (1999, 2000).

\section{GnRH ELISAs}

Three specific ELISAs, each a classical competitive assay, were used to measure the levels of sbGnRH, cGnRH-II and $\mathrm{sGnRH}$ in pituitary extract. The development of these assays has been described previously (Holland et al. 1998a). Each of the ELISAs has been characterized for use with striped bass pituitary extract (Holland 1999). In brief, the assays were performed in 96-well microtiter plates precoated with goat anti-rabbit IgG (Cayman Chemical Company, Ann Arbor, MI, USA). Specific antiserum no. 1668 was used for the sGnRH assay (King \& Millar 1985), no. 1076 for the sbGnRH assay (King \& Millar 1985) and anti-cGnRH-II for the cGnRH-II assay (Okuzawa et al. 1990). Synthetic sbGnRH (J E Rivier, Salk Institute, La Jolla, CA, USA), cGnRH-II (Peninsula Laboratories Inc.,
Balmont, CA, USA) and sGnRH (Bachem Biosciences Inc., Torrance, CA, USA) were used as standards. The enzymatic tracers consisted of GnRH coupled to acetylcholinesterase (Cayman Chemical Company). Each well contained $50 \mu \mathrm{l}$ sample/standard, $50 \mu \mathrm{l}$ antiserum and $50 \mu \mathrm{l}$ tracer. Ellman's reagent $(200 \mu \mathrm{l} / \mathrm{well}$; Cayman Chemical Company) was used for developing and optical density was read at $405 \mathrm{~nm}$.

The sensitivity of each assay was determined at $80 \%$ of the maximum binding $\left(80 \% \mathrm{~B} / \mathrm{B}_{0}\right)$ and was $6 \mathrm{pg} /$ well for sbGnRH, $7 \mathrm{pg} /$ well for cGnRH-II and $2 \mathrm{pg} /$ well for sGnRH. Cross-reactivities were calculated at $50 \% \mathrm{~B} / \mathrm{B}_{0}$ and were all $<0.6 \%$ except for the sGnRH assay which displayed a $3 \cdot 7 \%$ cross-reactivity with cGnRH-II. Intraand interassay coefficients of variation were determined for each assay at various points of binding (Holland 1999). In order to obtain readings within the most accurate range (intra-assay coefficients of variation $<15 \%$ ), pituitary extracts were diluted with ELISA buffer prior to analyses.

\section{Statistical analyses}

In order to detect differences in GnRH levels over time, data were analyzed for each reproductive cycle separately (September until July) using a one-way ANOVA followed by Duncan's New Multiple Range Test (SuperAnova; Abacus Concepts Inc., Berkeley, CA, USA). A similar analysis was performed using data collected over the entire sampling period (4 years for the females and 3 years for the males) to test whether significant differences existed among the maximum levels reached during a particular year. To analyze differences between the two maturity categories (juvenile versus maturing/mature), data collected during the second (males) or third (females) reproductive cycle were subjected to a two-way ANOVA (month vs maturity category) followed by the method of least squares. In all cases, significance was accepted at $P<0 \cdot 05$. Data are presented as means \pm S.E.M.

\section{Results}

\section{Pituitary GnRH levels in female striped bass}

All three forms of $\mathrm{GnRH}$ were present in the pituitary of female striped bass (Fig. 1) with sbGnRH being the dominant form followed by cGnRH-II and sGnRH, in a ratio of 100:10:1. Each of these forms could already be detected in pituitaries of 1-year-old juvenile females and showed monthly fluctuations. Each year, the levels of $\mathrm{sbGnRH}$ showed maximum values between the months March to June, coinciding with the natural breeding season for adult striped bass. Also cGnRH-II levels appeared to correlate to the natural spawning season but, in 

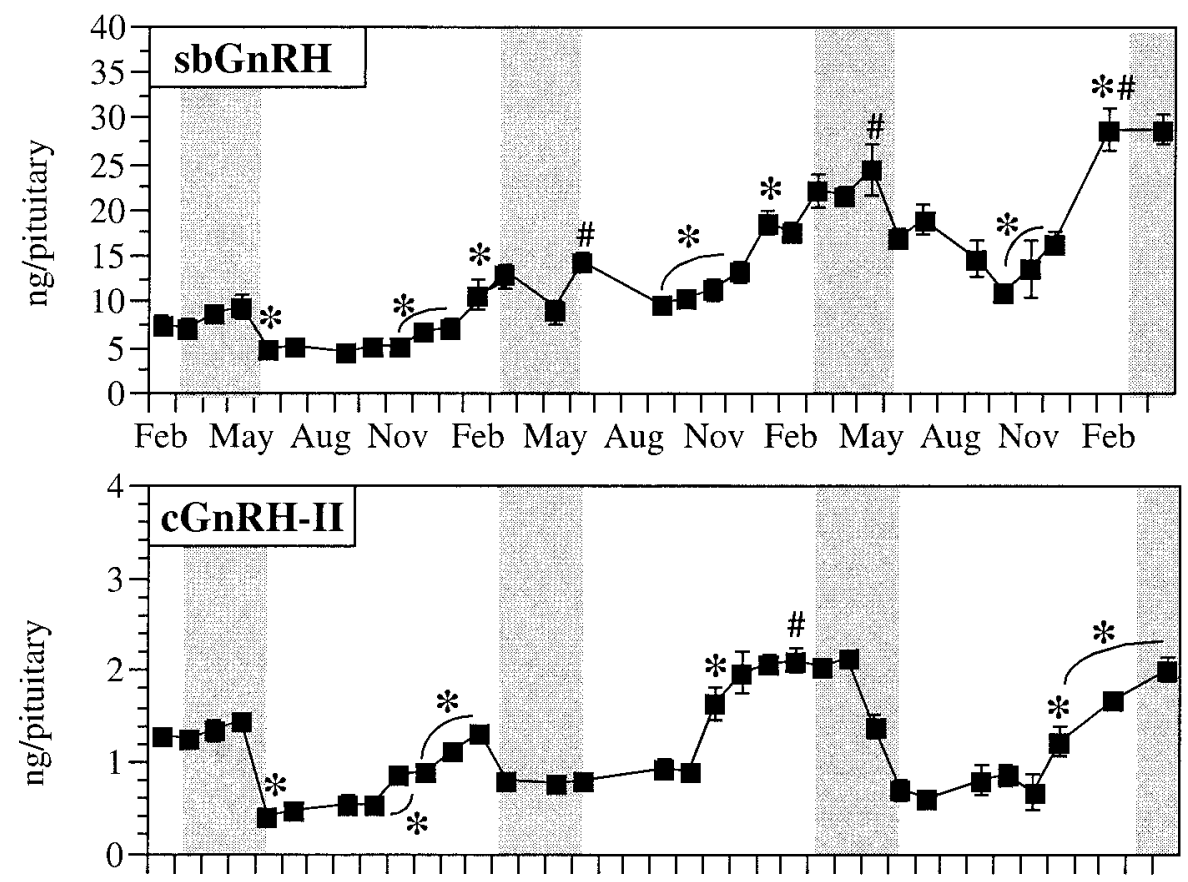

Feb May Aug Nov Feb May Aug Nov Feb May Aug Nov Feb

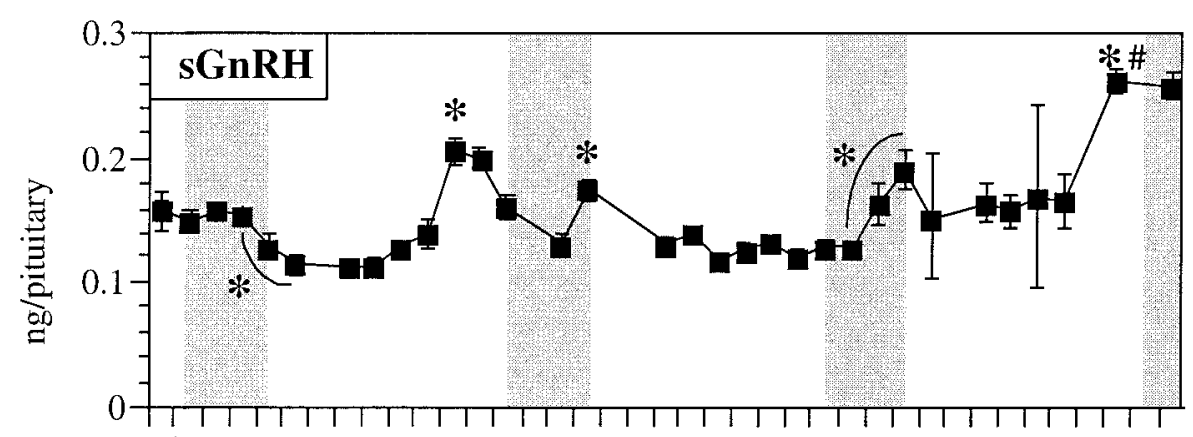

Feb May Aug Nov Feb May Aug Nov Feb May Aug Nov Feb

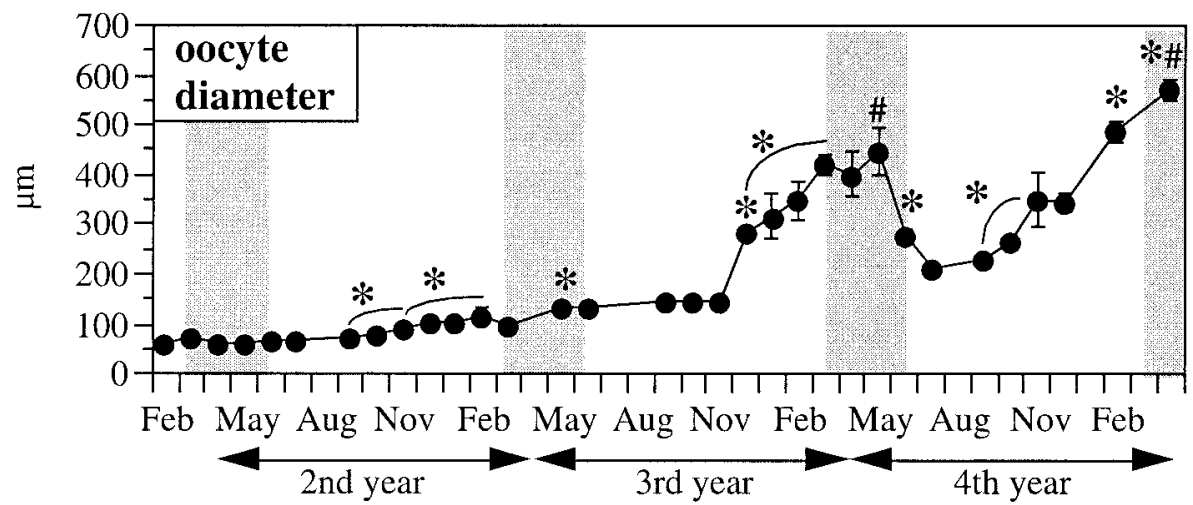

Figure 1 Monthly changes in the mean ( \pm S.E.M.) pituitary levels of sbGnRH, cGnRH-II and sGnRH and oocyte diameter in female striped bass from the second to the fourth year of life. For the third year, only data from maturing females were used. The vertical shaded bars indicate the natural spawning season for striped bass in the mid-Atlantic region. ${ }^{*} P<0 \cdot 05$, significant increases from the previous month or between the means indicated. $\# P<0 \cdot 05$, peak values which were significantly higher than the maximum values attained in the previous year. 
contrast to $\mathrm{sbGnRH}$, reached their maximum values prior to the breeding season. Fluctuations in sGnRH levels were more difficult to correlate to the reproductive season than those of sbGnRH and cGnRH-II since in some years they reached maximum values prior to (second year) and in others after (third year) the reproductive season. Throughout the course of the experiment sbGnRH levels, unlike those of cGnRH-II and sGnRH, were continually increasing, reaching higher maximum values each year. In spite of the increases in pituitary GnRH levels, all females remained immature during the first and second year and ovaries contained exclusively oogonia, oocytes in primary growth and some in early secondary growth (second year only) stages (for a description of ovarian development see Holland et al. 2000). During the third year, ovarian recrudescence took place in about $65 \%$ of the females and was accompanied by a sharp increase in mean oocyte diameter (Fig. 1, bottom panel). All 4-year-old females had developing oocytes and GSI and mean oocyte diameter reached higher values than those of 3-year-old pubertal fish.

Standardizing the pituitary GnRH levels for pituitary size (ng GnRH/mg protein; data not shown) created different profiles from those of non-standardized values. Juvenile 1-year-old fish had dramatically higher levels of all three $\mathrm{GnRH}$ forms in the pituitary than maturing 4-year-old females. High pituitary GnRH levels in young immature fish have also been reported for other species (Okuzawa et al. 1990, Holland et al. 1998a) and are the result of the extremely small size of the pituitary in young fish. Although a biological relevance for high $\mathrm{GnRH}$ pituitary levels in very young fish cannot be ruled out, we believe that, at least in striped bass, the absolute $\mathrm{GnRH}$ values (ng GnRH/pituitary) are a better indication of GnRH-releasing activity than standardized levels. This hypothesis is based on the observation that the absolute values more accurately reflect the changes in gonadal development in striped bass than standardized levels. In addition, the use of pituitary size to standardize pituitary $\mathrm{GnRH}$ levels is controversial. After all, GnRH is produced by the brain and is retained in the pituitary in the terminal endings of the GnRH neurons. Therefore, it is unlikely that increases in pituitary size, due to hypertropy of pituitary cells, are proportional to those in pituitary $\mathrm{GnRH}$ levels. Standardizing GnRH levels for pituitary size may mask increases in GnRH, in these instances. Based on this rationale, we present the absolute values only.

In pubertal, 3-year-old females, both sbGnRH and cGnRH-II levels increased concomitantly with the increases in mean oocyte diameter. However, about $35 \%$ of the 3-year-old females did not initiate ovarian recrudescence and mean oocyte diameter of these fish remained less than $200 \mu \mathrm{m}$ (Fig. 2). The levels of sbGnRH, cGnRH-II and sGnRH in the pituitary of these juvenile, 3 -year-old females were not significantly different from those of pubertal fish.
Pituitary GnRH levels in male striped bass

About $60-64 \%$ of the male striped bass reached sexual maturity during the first and second year of life while $100 \%$ matured during the third year (Holland et al. 2000). Sexual maturity was accompanied by an increase in GSI and fish were spermiating in the Spring (for duration of the spermiation periods see Fig. 3). Each consecutive year, mean GSI reached higher maximum values, indicating an increase in spermatogenic activity with age. Similarly, pituitary sbGnRH and cGnRH II levels, which remained low and unchanged during the first year, reached higher maximum values during the spermiation period of the third than that of the second year (Fig. 3). The levels of sGnRH started to increase only during the third year. Standardizing GnRH levels for pituitary size (ng $\mathrm{GnRH} / \mathrm{mg}$ protein) yielded similar results as for the females, e.g. high levels in juvenile young fish and low levels in older animals (data not shown). For reasons listed above (see 'Pituitary GnRH levels in female striped bass') the standardized data set will not be further discussed. During the first 2 years, about $40 \%$ of the males remained immature and, consequently, the GSI of those fish was significantly lower than that of mature males (Fig. 4). In spite of this difference in sexual maturity, the levels of the three GnRH forms in the pituitary of immature fish were similar to those of the mature males (Fig. 4; 2-year-old males only).

\section{Correlations between GnRH levels and other reproductive parameters}

Regression analysis using data from the months of September to April, a period during which most of the gonadal development occurred, yielded several linear relationships $(P<0 \cdot 05)$ between GnRH levels and other reproductive parameters, such as GSI, mean oocyte diameter and FSH and LH subunit mRNA levels (Table 1). Data on FSH and LH transcript levels were taken from previously published studies (Hassin et al. 1999, 2000). In 2- and 3-year-old females and 2-year-old males, sbGnRH and cGnRH-II levels showed a higher correlation to GSI and FSH and $\mathrm{LH}$ expression than sGnRH. GnRH levels from 3-year-old males correlated poorly to GSI and to gonadotropin levels. The lack of correlation in these fish was probably the result of the reduction in growth that was observed in the 1991 population from February to April. This reduced growth, which was the result of water quality problems, resulted in a lower pituitary size and hormone levels while GSI kept increasing in a normal fashion.

\section{Discussion}

All three GnRH forms produced by the striped bass brain were present in the pituitary in a ratio of 100:10:1 for 


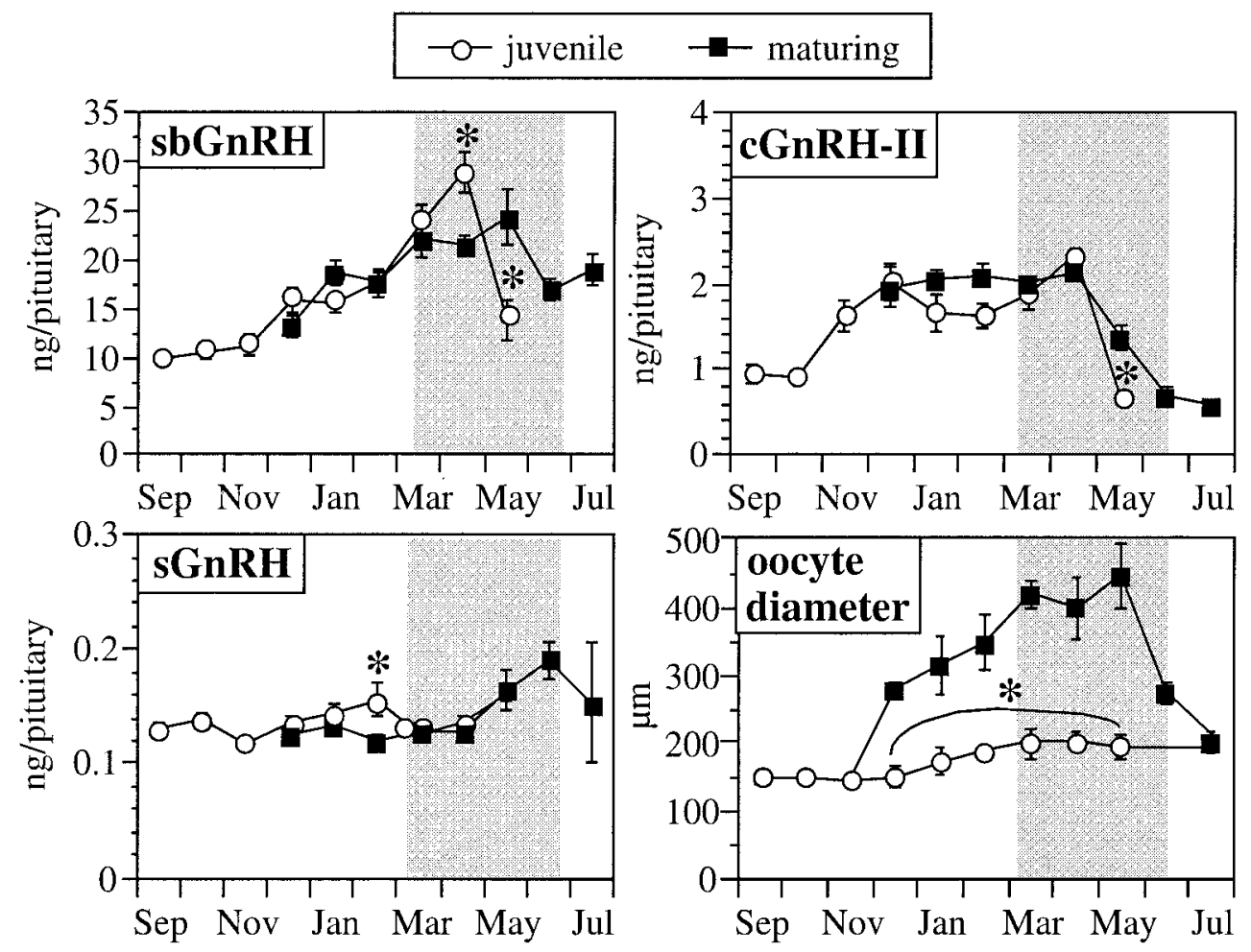

Figure 2 Changes in mean ( \pm S.E.M.) pituitary sbGnRH, cGnRH-Il and sGnRH levels and oocyte diameter in juvenile and maturing female striped bass sampled during their third year of life. The vertical shaded bars indicate the natural spawning season for striped bass. ${ }^{*} P<0 \cdot 05$, significant differences between juvenile and maturing fish.

sbGnRH:cGnRH-II:sGnRH. Within the order of perciformes a large variation exists in the number and types of GnRH that reach the pituitary. For example, similar to the situation in striped bass, all three GnRH forms have been detected in tilapia, Oreochromis mossambicus (Weber et al. 1997) and European seabass, Dicentrarchus labrax pituitaries (Rodriguez et al. 2000) with sbGnRH being the dominant form, followed by cGnRH-II. Pituitaries from other species, however, contained either sbGnRH alone (e.g. black seabream, Acanthopagrus schlegeli (Senthilkumaran et al. 1999) and African ciclid, Haplochromis burtoni (White et al. 1995)) or sbGnRH in combination with sGnRH (e.g. red seabream and striped knifejaw, Oplegnatus fasciatus (Senthilkumaran et al. 1999)) or cGnRH-II (gilthead seabream (Holland et al. 1998a)). It should be kept in mind, however, that some of these reports were based on few sampling points and the possibility cannot be ruled out that pituitaries of fish in other life or reproductive stages contain additional forms. The reason for GnRH multiplicity in the pituitary is still unclear. It is possible that the GnRH forms have different functions in the regulation of FSH and LH synthesis and release. It has also been hypothesized that the GnRH variants have different roles in regulating growth hormone
(Le Gac et al. 1993) or prolactin release (Weber et al. 1997). Perciformes, and fish in general, display a wide range of life histories. Therefore, different species may require a different regulation of the pituitary hormones, which control many physiological processes, such as reproduction, metabolism, osmoregulation and growth (Fontaine 1993). The role each GnRH variant plays in the various physiological functions needs to be addressed further but, based on the findings of an increasing number of studies, it has become clear that the functions of $\mathrm{GnRH}$ at the pituitary level may be more diverse than initially thought.

Seabream GnRH is believed to be the most important form in the regulation of gonadal function in perciformes (Powell et al. 1995, Gothilf et al. 1996, Holland et al. 1998a, Senthilkumaran et al. 1999). The finding that sbGnRH is the dominant form in the striped bass pituitary and that its levels increase during the natural period of gonadal recrudescence suggest that, also in this species, sbGnRH plays an important role in regulating reproduction. However, in addition to sbGnRH, the levels of cGnRH-II showed a positive correlation to oocyte diameter and GSI. The pituitary levels of cGnRH-II are tenfold lower than those of $\mathrm{sbGnRH}$, but the higher potency of 

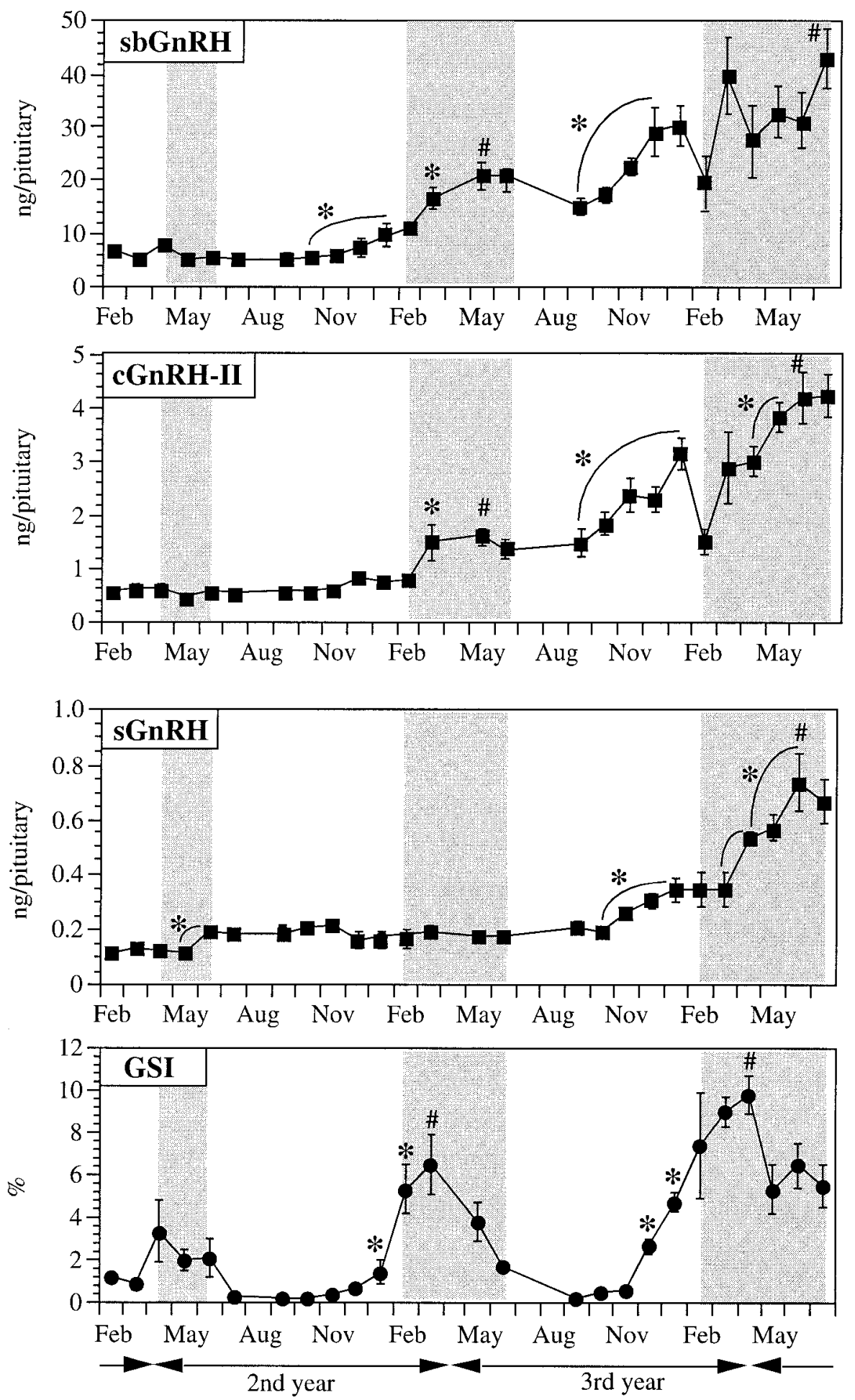

Figure 3 Monthly changes in the mean ( \pm S.E.M.) pituitary levels of sbGnRH, cGnRH-II and sGnRH and GSI in mature male striped bass from the second to the third year of life. The vertical shaded bars indicate the periods during which spermiating males were observed. ${ }^{*} P<0 \cdot 05$, significant increases from the previous month or between the means indicated. $\# P<0 \cdot 05$, peak values which were significantly higher than the maximum values attained in the previous year. 


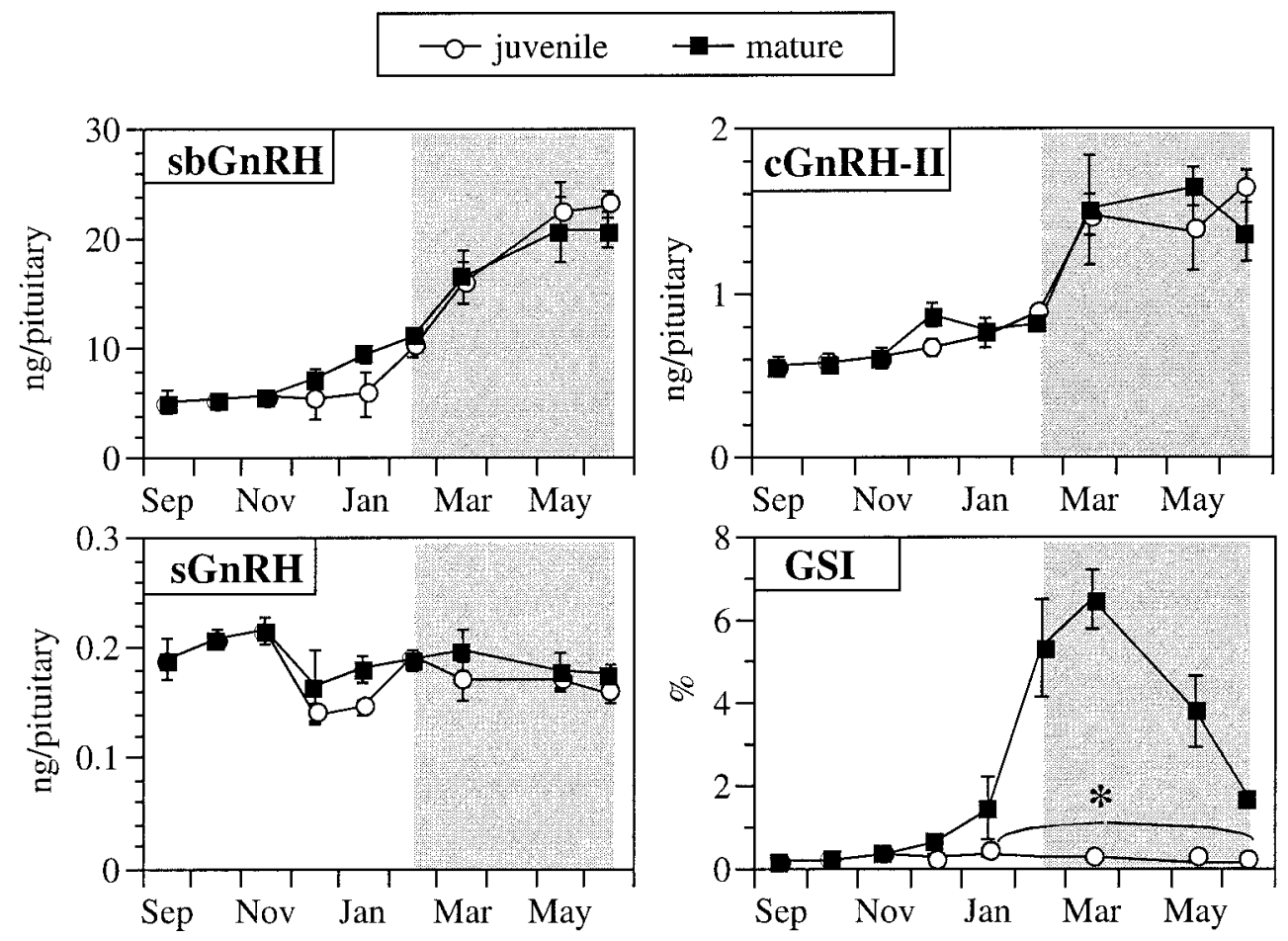

Figure 4 Changes in mean ( \pm S.E.M.) pituitary sbGnRH, cGnRH-II and sGnRH levels and GSI in juvenile and mature male striped bass during their second year of life. The vertical shaded bars indicate the period during which spermiating males were observed. ${ }^{*} P<0 \cdot 05$, significant differences between juvenile and mature fish.

Table 1 Correlation, and corresponding coefficients $\left(r^{2}\right)$, between GnRH forms (sbGnRH (sb), cGnRH-Il (cll) and sGnRH (s)) and other reproductive parameters (GSI, oocyte diameter, LH protein levels and FSH and LH $\alpha$ and $\beta$ subunit mRNA levels) during the period of gonadal recrudescence (September to April). Regression analyses were performed for maturing fish only

\begin{tabular}{|c|c|c|c|c|}
\hline & \multicolumn{2}{|l|}{ Females } & \multicolumn{2}{|l|}{ Males } \\
\hline & 3 years old & 4 years old & 2 years old & 3 years old \\
\hline \multicolumn{5}{|l|}{ Parameter } \\
\hline GSI (\%) & $\mathrm{sb}>\mathrm{cll}$ & $\mathrm{sb}>\mathrm{cll}>\mathrm{s}$ & $\mathrm{sb}>\mathrm{cll}$ & $\mathrm{s}>\mathrm{cll}$ \\
\hline$r^{2}$ & $0 \cdot 41>0 \cdot 26$ & $0.53>0.35>0.24$ & $0 \cdot 49>0 \cdot 13$ & $0 \cdot 19>0 \cdot 08$ \\
\hline Oocyte diameter $(\mu \mathrm{m})$ & $\mathrm{sb}>\mathrm{cll}$ & $\mathrm{cll}>\mathrm{sb}>\mathrm{s}$ & & \\
\hline$r^{2}$ & $0 \cdot 58>0 \cdot 40$ & $0 \cdot 49>0 \cdot 44>0 \cdot 36$ & & \\
\hline LH (ng/pituitary) & $\mathrm{sb}>\mathrm{cll}$ & $\mathrm{sb}>\mathrm{cll}$ & $\mathrm{sb}>\mathrm{cll}$ & - \\
\hline$r^{2}$ & $0 \cdot 43>0 \cdot 33$ & $0 \cdot 22>0 \cdot 20$ & $0 \cdot 22>0 \cdot 16$ & \\
\hline$\alpha-\mathrm{mRNA}(\mathrm{fmol})$ & $\mathrm{cll}>\mathrm{sb}$ & - & $\mathrm{sb}$ & cll \\
\hline$r^{2}$ & $0 \cdot 23>0 \cdot 18$ & & $0 \cdot 28$ & $0 \cdot 10$ \\
\hline FSH $\beta$ mRNA (fmol) & cll & sb>cll (neg.) & - & - \\
\hline$r^{2}$ & $0 \cdot 10$ & $0.23>0.08$ & & \\
\hline LH $\beta$ mRNA (fmol) & $s b>c l l$ & - & $\mathrm{sb}$ & $\mathrm{cll}>\mathrm{s}>\mathrm{sb}$ \\
\hline$r^{2}$ & $0 \cdot 28>0 \cdot 27$ & & $0 \cdot 39$ & $0 \cdot 13>0 \cdot 12>0 \cdot 10$ \\
\hline
\end{tabular}

A dash indicates a comparison which did not yield a significant linear relationship $(P>0 \cdot 05)$. A negative correlation is indicated by (neg.).

cGnRH-II in inducing LH release (Mylonas et al. 1999) may compensate for the lower concentration of cGnRH-II in the pituitary. The present data do not support a potential role for $\mathrm{sGnRH}$ in the regulation of gonadal growth in striped bass. The levels of $\mathrm{sGnRH}$ in the pituitary were very low, often close to the minimum 
detection limit of the assay, and sGnRH levels showed only a weak correlation, if at all, to oocyte diameter and GSI. Interestingly, sbGnRH and cGnRH-II levels correlated to a greater extent to GSI and LH pituitary content than to FSH and $\mathrm{LH}$ transcript levels, even though these latter have been shown to be directly stimulated by $\mathrm{GnRH}$ in adult male striped bass (Hassin et al. 1998). The weak correlation between GnRH and FSH or LH mRNA levels is probably due to the high variation in transcript levels that existed among individuals, which also explains the relatively low correlation coefficient between LH mRNA and LH pituitary content (Hassin et al. 1999). Correlations between GnRH levels and plasma LH levels have not been made since plasma LH levels remained low and unchanged throughout the experiment (Hassin et al. 1999, 2000). Low plasma LH levels have also been reported in adult captive striped bass (Mylonas et al. 1997, 1998). Unfortunately, the relationships between the GnRH forms and plasma FSH levels remain unknown, since an immunassay for FSH is not yet available for this, or any other perciform species. Based on the present findings it can be concluded that gonadotropin function and gonadal development in striped bass is regulated by sbGnRH and/or cGnRH-II. More studies are needed to elucidate the specific roles of both GnRH forms in striped bass in the various reproductive processes.

Ontogeny studies using a variety of species showed that the GnRH system in fish becomes established early in development (Chiba et al. 1994, Feist \& Schreck 1996, Parhar 1997). The levels of GnRH are low in pituitaries of juvenile fish but increase during sexual maturation, whether spontaneously occurring (Okuzawa et al. 1990, Amano et al. 1992, 1993, Holland et al. 1998a) or artificially induced (Dufour et al. 1985). In striped bass, sbGnRH and cGnRH-II were abundantly present in pituitaries of 1-year-old juvenile females, which were at least 2 years away from reaching sexual maturity. In addition, the GnRH profiles of immature and maturing siblings (in 3- and 2-year-old females and males respectively) were very similar, despite the fact that gonadal growth took place in maturing fish only. Based on these findings, it can be concluded that the availability of $\mathrm{GnRH}$ in the pituitary is not limiting the onset of puberty in striped bass and that the timing of puberty may depend on other maturational processes in the pituitary or gonad. Although the abundance of $\mathrm{GnRH}$ in the pituitary is not a direct indication of $\mathrm{GnRH}$ release, $\mathrm{FSH}$ and $\mathrm{LH}$ transcript and protein (LH only) levels were elevated in juvenile 2-year-old female and male fish (Hassin et al. 1999, 2000). Steroids are known to exert positive feedback actions on gonadotropin levels in immature fish (e.g. Crim \& Evans 1982, Montero et al. 1995, Holland et al. 1998b). Since the levels of the major gonadal steroids were low to non-detectable in 2-year-old females and immature 2-year-old males (Holland et al. 2000), it can be assumed that the increased gonadotropic activity observed during the second year was the result of an increase in GnRH release. In all years, except the first, increases in GnRH pituitary content correlated with an increased gonadotropic activity in the pituitary. In 1-year-old females, the levels of GnRH, but not those of pituitary FSH and $\mathrm{LH}$, were elevated, suggesting that their immature state may have been caused by a non-responsive pituitary. In contrast, in 1-year-old maturing males an increase in GSI and FSH and LH transcript levels (S Hassin, M C H Holland \& Y Zohar, unpublished results) could be observed, while $\mathrm{GnRH}$ levels remained low and unchanged. It is unclear why the correlation between GnRH levels and testicular development was absent during this first year but it can be hypothesized that GnRH synthesis and transport to the pituitary equalled $\mathrm{GnRH}$ release at this time, resulting in relatively unchanging pituitary GnRH content.

Interestingly, seasonally changing $\mathrm{GnRH}$ profiles were already apparent in juvenile 1- and 2-year-old striped bass and continued throughout sexual maturation. Each year, except for 1-year-old males, sbGnRH and cGnRH-II pituitary levels started to increase in the Fall, reached their maximum values in the Spring and declined again thereafter. In temperate regions, reproduction of seasonally breeding animals is regulated predominantly by photoperiod. Changes in light:darkness cycles are relayed to the GnRH system, which, in turn, stimulates the activity of the pituitary-gonad axis (Munro et al. 1990). The present findings suggest that this may also be the case in the striped bass, since the sbGnRH and cGnRH-II profiles corresponded to those of mean oocyte diameter or GSI. The observation that juvenile fish displayed the same seasonality in pituitary $\mathrm{GnRH}$ levels as maturing fish indicates that the photoperiodic control of the GnRH system becomes established early in development in this species. In the masu salmon, a short photoperiod stimulated testicular development in underyearling precocious males via the activation of $\mathrm{sGnRH}$ synthesis (Amano et al. 1995). A similar increase was observed in castrated underyearling precocious males, indicating that the increases in $\mathrm{sGnRH}$ transcript levels were independent of gonadal steroids (Amano et al. 1999). These correlations between short photoperiod and pituitary sGnRH, FSH and LH content were absent in juvenile males and females (Amano et al. 1994). Therefore, the GnRH system of precocious, but not that of juvenile, masu salmon was responsive to photoperiodic changes. The situation in the masu salmon is clearly different from that in striped bass and this observation supports our earlier hypothesis that an unresponsive GnRH system is not the cause of the immature state of the gonads in juvenile striped bass. As shown by Hassin et al. (1999) pubertal females have a lower expression of the gonadotropin genes compared with 4-year-old striped bass females, and 3-year-old maturing females have higher 
FSH mRNA levels compared with their immature siblings. These findings suggest that the differences in maturity state were caused by differences in gonadotropic activity. Alternatively, the gonads may play an important role in the timing of puberty. Studies in the rainbow trout, Oncorhynchus mykiss, have shown that oocytes need to reach a certain critical size before they can be recruited into the secondary growth phase, or vitellogenesis, a process believed to be controlled by FSH (Tyler et al. 1991, 1997). Unfortunately, very little is known about the regulation of the early stages of oocyte growth in fish, e.g. oogonial differentiation and primary oocyte growth. Mean oocyte diameter of striped bass gradually increased during the first 2 years of life. The lack of seasonality in this growth profile as well as the extremely low expression of the FSH and LH genes during the first years (Hassin et al. 1999) suggest that early oocyte growth is not under gonadotropic control in striped bass. This is supported by previous findings that ovaries of juvenile 2-year-old fish displayed a limited responsiveness to experimentally elevated gonadotropin levels (Holland et al. 1998b). A better understanding of the regulation of the early stages of gonadal development, including the gonadotropin receptors, is extremely important for the study of puberty and needs to be investigated more intensely.

In summary, all three native GnRH forms were present in the striped bass pituitary, irrespective of sex and stage of maturity. Gonadal development may be regulated by $\mathrm{sbGnRH}$, cGnRH-II or a combination of both since they are present in higher levels in the pituitary than sGnRH (sbGnRH>cGnRH-II) and both can be correlated to FSH and LH levels and gonadal parameters, such as GSI and oocyte diameter. Pituitary sbGnRH and cGnRH-II levels were elevated already in young juvenile fish, and displayed seasonal changes similar to those observed in older mature fish. These findings indicate that the development of a 'mature' GnRH system may not be limiting the onset of puberty in this species. Critical events in determining the timing of puberty in striped bass may be related not only to the activity of the GnRH system, but also to a sufficient synthesis and release of FSH into the circulation and the development of gonadotropin-responsive gonads.

\section{Acknowledgements}

This research was supported by grants from Maryland Sea Grant (NA46RG0091), US-Israel Binational Agricultural R\&D Fund (IS-2634-95C), and USDA (95-372032117) to Y Z. This publication is contribution no. 530 from the Center of Marine Biotechnology. We would like to thank Mr Scott Wehage and Dr Yoav Gothilf for their help with the fish samplings, Mr Steven Rodgers for maintaining the fish, and Dr Constantinos Mylonas for critically reading the manuscript.

\section{References}

Amano M, Aida K, Okumoto N \& Hasegawa Y 1992 Changes in salmon GnRH and chicken GnRH-II content in the brain and pituitary, and GtH content in the pituitary in female masu salmon, Oncorhynchus masou, from hatching through ovulation. Zoological Sciences 9 375-386.

Amano M, Aida K, Okumoto N \& Hasegawa Y 1993 Changes in levels of GnRH in the brain and pituitary and GtH in the pituitary in male masu salmon, Oncorhynchus masou, from hatching to maturation. Fish Physiology and Biochemistry 11 233-240.

Amano M, Okumoto N, Kitamura S, Ikuta K, Suzuki Y \& Aida K 1994 Salmon gonadotropin-releasing hormone and gonadotropin are involved in precocious maturation induced by photoperiod manipulation in underyearling male masu salmon, Oncorhynchus masou. General and Comparative Endocrinology 95 368-373.

Amano M, Hyodo S, Kitamura S \& Aida K 1995 Short photoperiod accelerates preoptic and ventral telencephalic salmon $\mathrm{GnRH}$ synthesis and precocious maturation in underyearling male masu salmon. General and Comparative Endocrinology 99 22-27.

Amano M, Ikuta K, Kitamura S \& Aida K 1999 Effects of photoperiod on salmon GnRH mRNA levels in brain of castrated underyearling precocious male masu salmon. General and Comparative Endocrinology 115 70-75.

Anglade I, Zandbergen T \& Kah O 1993 Origin of the pituitary innervation in the goldfish. Cell and Tissue Research 273 345-355.

Chiba A, Oka S \& Honma Y 1994 Ontogenetic development of gonadotropin-releasing hormone-like immunoreactive neurons in the brain of the chum salmon, Oncorhynchus keta. Neuroscience Letters 178 51-54.

Crim LW \& Evans DM 1982 Positive testosterone feedback on gonadotropic hormone in the rainbow trout. In Proceedings of the Second International Symposium on the Reproductive Physiology of Fish, p 23. Eds CJJ Richter \& HJT Goos. Wageningen, The Netherlands.

Dufour S, Fontaine YA \& Kerdelhue B 1985 Increase in brain and pituitary radioimmoassayable gonadotropin releasing hormone $(\mathrm{GnRH})$ in the European silver eel treated with sexual steroid or human chorionic gonadotropin. Neuropeptides 6 495-502.

Dufour S, Montero M, Belle NL, Bassompierre M, King JA, Millar RP, Peter RE \& Fontaine Y-A 1993 Differential distribution and response to experimental sexual maturation of two forms of brain gonadotropin-releasing hormone $(\mathrm{GnRH})$ in the European eel, Anguilla anguilla. Fish Physiology and Biochemistry 11 99-106.

Feist G \& Schreck CB 1996 Brain-pituitary-gonadal axis during early development and sexual differentiation in the rainbow trout, Oncorhynchus mykiss. General and Comparative Endocrinology 102 394-409.

Fink G 1988 Gonadotropin secretion and its control. In The Physiology of Reproduction, vol. 2, pp 1349-1377. Eds E Knobil \& J Neill. New York: Raven Press.

Fontaine Y-A 1993 Adaptations versus accomodations: some neuroendocrine aspects in teleost fish. Fish Physiology and Biochemistry 11 147-154.

Gothilf Y, Elizur A \& Zohar Y 1995 Three forms of gonadotropin-releasing hormone in gilthead seabream and striped bass: physiological and molecular studies. In Proceedings of the Fifth International Symposium on the Reproductive Physiology of Fish, pp 52-54. Eds FW Goetz \& P Thomas. Austin, TX, USA.

Gothilf Y, Munoz-Cueto JA, Sagrillo CA, Selmanoff M, Chen TT, Kah O, Elizur A \& Zohar Y 1996 Three forms of gonadotropinreleasing hormone in a perciform fish (Sparus aurata): cDNA characterization and brain localization. Biology of Reproduction $\mathbf{5 5}$ 636-645.

Hassin S, Gothilf Y, Blaise O \& Zohar Y 1998 Gonadotropin-I and -II subunit gene expression of male striped bass (Morone saxatilis) 
after gonadotropin-releasing hormone analog injection: quantitation using an optimized ribonuclease protection assay. Biology of Reproduction 58 1233-1240.

Hassin S, Holland MCH \& Zohar Y 1999 Ontogeny of LH and FSH gene expression during pubertal development in the female striped bass, Morone saxatilis (Teleostei). Biology of Reproduction $\mathbf{6 1}$ $1608-1615$.

Hassin S, Holland MCH \& Zohar Y 2000 Early maturity in the male striped bass: FSH and $\mathrm{LH}$ gene expression and their regulation by GnRHa and testosterone. Biology of Reproduction 63 1691-1697.

Holland MCH 1999 The Onset of Puberty in Striped Bass, Morone saxatilis: Studies on the Activation of the Brain-Pituitary-Gonad Axis. $\mathrm{PhD}$ Thesis. University of Maryland, College Park, MD, USA.

Holland MC, Mylonas CC \& Zohar Y 1996 Sperm characteristics of precocious 1-year-old male striped bass, Morone saxatilis. Journal of the World Aquaculture Society 27 208-212.

Holland MCH, Gothilf Y, Meiri I, King JA, Okuzawa K, Elizur A \& Zohar Y 1998a Levels of the native forms of GnRH in the pituitary of the gilthead seabream, Sparus aurata, at several characteristic stages of the gonadal cycle. General and Comparative Endocrinology 112 394-405.

Holland MCH, Hassin S \& Zohar Y $1998 b$ The effects of long-term testosterone, gonadotropin-releasing hormone agonist and pimozide treatments on gonadotropin II levels and ovarian development in juvenile female striped bass (Morone saxatilis). Biology of Reproduction 59 1153-1162.

Holland MCH, Hassin S \& Zohar Y 2000 Gonadal development and plasma steroid levels during pubertal development in captive-reared striped bass, Morone saxatilis. Journal of Experimental Zoology 286 49-63.

King JA \& Millar RP 1985 Multiple molecular forms of gonadotropin-releasing hormone in teleost fish brain. Peptides $\mathbf{6}$ 689-694.

Le Gac F, Blaise O, Fostier A, Le Bail PY, Loir M, Mourot B \& Weil C 1993 Growth hormone (GH) and reproduction: a review. Fish Physiology and Biochemistry 11 219-232.

Lescheid DW, Terasawa E, Abler LA, Urbanski HF, Warby CM, Millar RP \& Sherwood NM 1997 A second form of gonadotropin-releasing hormone $(\mathrm{GnRH})$ with characteristics of chicken GnRH-II is present in the primate brain. Endocrinology 138 $5618-5629$.

Montaner AD, Somoza GM, King JA, Bianchini JJ, Bolis CG \& Affanni JM 1998 Chromatographic and immunological identification of $\mathrm{GnRH}$ (gonadotropin-releasing hormone) variants. Occurrence of mammalian and a salmon-like GnRH in the forebrain of a eutherian mammal: Hydrochaeris hydrochaeris (Mammalia, Rodentia). Regulatory Peptides 73 197-204.

Montero M, Le Belle N, King JA, Millar RP \& Dufour S 1995 Differential regulation of the two forms of gonadotropin-releasing hormone ( $\mathrm{mGnRH}$ and $\mathrm{cGnRH}-\mathrm{II})$ by sex steroids in the European female silver eel (Anguilla anguilla). Neuroendocrinology 61 $525-535$.

Munro AD, Scott AP \& Lam TJ 1990 Reproductive Seasonality in Teleosts: Environmental Influences. Boca Raton, Florida: CRC Press.

Mylonas CC, Scott AP, Vermeirssen ELM \& Zohar Y 1997 Changes in plasma gonadotropin II and sex steroid hormones, and sperm production of striped bass after treatment with controlled-release gonadotropin-releasing hormone agonist-delivery systems. Biology of Reproduction 57 669-675.

Mylonas CC, Woods LCI, Thomas P \& Zohar Y 1998 Endocrine profiles of female striped bass (Morone saxatilis) in captivity, during post-vitellogenesis and induction of final oocyte maturation via controlled-release GnRHa-delivery systems. General and Comparative Endocrinology 110 276-289.

Mylonas C, Blaise O, Gothilf Y \& Zohar Y 1999 Gonadotropinreleasing activities in striped bass (Morone saxatilis) of the three native forms of gonadotropin-releasing hormone $(\mathrm{GnRH})$ and of novel agonists. In Proceedings of the Sixth International Symposium on the Reproductive Physiology of Fish, p 451. Eds B Norberg, OS Kjesbu, GL Taranger, E Andersson \& SO Stefansson. Bergen, Norway.

Ojeda SR \& Urbanski HF 1994 Puberty in the rat. In The Physiology of Reproduction, pp 363-409. Eds E Knobil \& J Neill. New York: Raven Press.

Oka Y 1997 GnRH neuronal system of fish brain as a model system for the study of peptidergic neuromodulation. In GnRH Neurons: Genes to Behavior, pp 245-276. Eds IS Parhar \& Y Sakuma. Tokyo: Brain Shuppan.

Okuzawa K, Amano M, Kobayashi M, Aida K, Hanyu I, Hasegawa Y \& Miyamoto K 1990 Differences in salmon GnRH and chicken GnRH-II contents in discrete brain areas of male and female rainbow trout according to age and stage of maturity. General and Comparative Endocrinology 80 116-126.

Okuzawa K, Granneman J, Bogerd J, Goos HJT, Zohar Y \& Kagawa H 1997 Distinct expression of GnRH genes in the red seabream brain. Fish Physiology and Biochemistry 17 71-79.

Parhar IS 1997 GnRH in tilapia: three genes, three origins and their roles. In GnRH Neurons: Genes to Behavior, pp 99-122. Eds IS Parhar \& Y Sakuma. Tokyo: Brain Shuppan.

Plant TM 1994 Puberty in primates. In The Physiology of Reproduction, vol. 2, pp 453-485. Eds E Knobil \& J Neill. New York: Raven Press.

Powell JFF, Zohar Y, Elizur A, Park C, Fisher WH, Craig AG, Rivier JE, Lovejoy DA \& Sherwood NM 1994 Three forms of gonadotropin-releasing hormone characterized from brain of one species. PNAS 91 12081-12085.

Powell JFF, Fischer WH, Park M, Craig AG, Rivier JE, White SA, Francis RCF, Fernald RD, Licht P, Warby C \& Sherwood NM 1995 Primary structure of a solitary form of gonadotropin-releasing hormone $(\mathrm{GnRH})$ in cichlid pituitary: three forms of $\mathrm{GnRH}$ in brain of cichlid and pumkinseed fish. Regulatory Peptides 57 43-53.

Rastogi RK, Di Meglio M \& Iela L 1990 Immunoreactive luteinizing hormone-releasing hormone in the frog (Rana esculenta) brain: distribution pattern in the adult, seasonal changes, castration effects, and developmental aspects. General and Comparative Endocrinology 78 444-458.

Rodriguez L, Carillo M, Sorbera LA, Soubrier MA, Mananos E, Holland MCH, Zohar Y \& Zanuy S 2000 Pituitary levels of three forms of $\mathrm{GnRH}$ in the male European seabass (Dicentrarchus labrax, L.) during sex differentiation and puberty. General and Comparative Endocrinology 120 67-74.

Schreibman MP, Holtzman S \& Margolis-Nunno H 1991 Maturation and ageing of the reproductive system. In Vertebrate Endocrinology: Fundamentals and Biomedical Implications, vol. 4, part A, pp 343-377. Eds PKT Pang, MP Schreibman \& R Jones. San Diego: Academic Press.

Senthilkumaran B, Okuzawa K, Gen K, Ookura T \& Kagawa H 1999 Distribution and seasonal variations in levels of three native GnRHs in the brain and pituitary of perciform fish. Journal of Neuroendocrinology 11 181-186.

Tyler CR, Sumpter JP \& Campbell PM 1991 Uptake of vitellogenin into oocytes during early vitellogenic development in the rainbow trout, Oncorhynchus mykiss (Walbaum). Journal of Fish Biology 38 681-689.

Tyler CR, Pottinger TG, Coward K, Prat F, Beresford N \& Maddix S 1997 Salmonid follicle-stimulating hormone (GtH I) mediates vitellogenic development of oocytes in the rainbow trout, Oncorhynchus mykiss. Biology of Reproduction 57 1238-1244.

Weber GM, Powell JFF, Park M, Fischer WH, Craig AG, Rivier JE, Nanakorn U, Parhar IS, Ngamvongchon S, Grau EG \& Sherwood NM 1997 Evidence that gonadotropin-releasing hormone (GnRH) functions as a prolactin-releasing factor in a teleost fish (Oreochromis mossambicus) and primary structures for three native $\mathrm{GnRH}$ molecules. Journal of Endocrinology 155 121-132. 
White SA, Kasten TL, Bond CT, Adelman JP \& Fernald RD 1995 Three gonadotropin-releasing hormone genes in one organism suggest a novel role for an ancient peptide. PNAS 92 8363-8367.

Yu KL, Nahorniak CS, Peter RE, Corrigan A, Rivier JE \& Vale WW 1987 Brain distribution of radioimmunoassayable gonadotropin-releasing hormone in female goldfish: seasonal variation and periovulatory changes. General and Comparative Endocrinology 67 234-246.
Zohar Y, Elizur A, Sherwood NM, Powell JFF, Rivier JE \& Zmora N 1995 Gonadotropin-releasing activities of the three native forms of gonadotropin-releasing hormone present in the brain of gilthead seabream, Sparus aurata. General and Comparative Endocrinology 97 289-299.

Received 7 August 2000

Accepted 23 February 2001 